\title{
Teaching Preservation to Students Archivists at University College London
}

\author{
JONATHAN RHYS-LEWIS \\ ICA Representative, United Kingdom \\ e-mail: jonathan.rhys-lewis@ntlworld.com
}

Teaching Preservation to Students Archivists at University College London

\begin{abstract}
This paper will outline the development of the teaching of preservation to Masters students on the University of College London, Masters in Archives \& Records Management qualification. It explores the evolving structure of this element of the teaching that focuses on a combination of student expectation and professional need. The paper further considers the approaches that have been taken to ensure that the students connect with this theoretical aspect of their learning. The author makes the case for a specialist in the subject of collection care, and shows how this enhances learning amongst the students. Additionally, this paper will investigate the increased challenges of promoting preservation in a changing professional environment, when the pressures on resources and modes of traditional access to archival records is causing ever-greater reliance on digitisation as a means of preservation. The author hopes that by outlining the current approach to teaching preservation in the UK, other countries will consider and explore similar models.
\end{abstract}

Key words: preservation, training, education, University College London

Insegnare la conservazione agli studenti di archivistica dell’University College di Londra

\section{SINTESI}

Questo intervento illustrerà lo sviluppo dell'insegnamento della conservazione agli studenti del Master in Gestione degli archivi e dei documenti presso l'Università di Londra. Esso esplora la struttura in evoluzione di questo aspetto dell'insegnamento che si concentra su una combinazione di aspettative degli studenti e di una necessità professionale. L'articolo approfondisce inoltre gli approcci che sono stati adottati per garantire che gli studenti approfondiscano questo aspetto teorico del loro apprendimento. L'autore esemplifica il caso di uno specialista curatore di raccolte, e mostra come questo migliori l'apprendimento tra gli studenti. Inoltre, questo testo indagherà le crescenti sfide della conservazione in un ambiente professionale in continua evoluzione, quando le pressioni sulle risorse e le modalità di accesso tradizionale alle registrazioni d'archivio provocano una sempre maggiore dipendenza dalla digitalizzazione come mezzo di conservazione. L'autore spera che, definendo l'attuale approccio alla conservazione dell'insegnamento nel Regno Unito, altri Paesi prenderanno in considerazione e esploreranno modelli simili.

Parole chiave: conservazione, formazione, University College di Londra

\section{Poučevanje materialnega varstva arhivskega gradiva na University College London}

\section{IZVLEČEK}

$\mathrm{V}$ tem prispevku je predstavljen razvoj poučevanja materialnega varstva arhivskega gradiva za študente magistrskega študija na University College London, magistrski študijski program Arhivistike in dokumentologije. Raziskuje spreminjajočo se strukturo tega elementa poučevanja, ki se osredotoča na kombinacijo pričakovanj študentov in poklicnih potreb. V članku so obravnavani tudi pristopi, ki zagotavljajo, da se študenti povezujejo s teoretičnim vidikom svojega učenja. Poleg tega avtor v prispevku predstavlja vedno večje izzive promoviranja materialnega varstva $\mathrm{v}$ spreminjajočem se poklicnem okolju, ko pritiski na vire in načine tradicionalnega dostopa do arhivskega gradiva povzročajo vedno večjo odvisnost od digitalizacije kot sredstva za ohranjanje gradiva. Avtor upa, da bo z opisom sedanjega pristopa $\mathrm{k}$ poučevanju materialnega varstva $\mathrm{v}$ Združenem kraljestvu vzpodbudil druge države $\mathrm{k}$ preučitvi in razmisleku o uporabi podobnih modelov.

Ključne besede: materialno varstvo, usposabljanje, izobraževanje, University College London 
If, as archive professionals, we accept that the key objective is to ensure that the collections we are responsible for not only survive, but that we can provide ready access to the information they contain, then it is imperative that we rigorously pursue the education of all involved in the process of archiving to know and understand the risks to these collections. What we need are fully-rounded professionals, who have both an awareness and appreciation of how the materials that consist of the archival collections in their care react and respond to the storage environments in which they are kept.

Our modern world requires many things from those who are the custodians of history - a wide knowledge of the collections and what they contain, the links, perceived or otherwise between archive objects $\mathrm{a}$ and $\mathrm{b}$, and also the inter-relationships with y and $\mathrm{z}$, and so on. Our users are also very concerned about how archives look after the collections (the stewardship of the resource), maybe not so much because they care about conservation per se, but specifically so they can have access to the information it contains. To achieve this aim of long-term preservation we need to consider a wide range of risks and impacts on the collections.

So, to achieve these multi-faceted requirements, the modern day archivist needs a wide range of skills, often far-removed from our perception of the role - someone who selects the key information from the mountains of information produced by persons, organisations and corporations, interprets the sources of the information and makes this available in a structured and cohesive form via a catalogue. The archivist needs to be a diplomat, a negotiator, a funding guru, an accountant, a teacher and a social worker. In addition to these new skills, the archivist also needs to be a collection care advocate.

Over the last 25 years, generations of archivists have wrestled with the changes that have been thrust upon them, compromising and developing to meet new pressures and demands. However, the profession cannot rely on a process of evolution, and needs to ensure that we embed common standards of approach are embedded in new and old professionals alike. This formalisation is most clearly defined via learning; training comes after. So, it is also important that archivists be taught a wide spectrum of skills, and preferably at the beginning of their careers, via formal education, and most importantly during their studies at degree level.

It is fortunate that University College London commissions the author to teach new archivists about collection care, and this role is an Honorary Lecturer delivering the Curation \& Stewardship and Collections Care modules as part of the Masters in Archives and Records Management. In addition, the author is also a co-author, with Dr. Helen Forde, of the second edition of the successful book Preserving Archives, published by Facet in March 2013. This book is now a key text for the UCL MARM and continues to sell both in the UK and across the world, in both analog and digital editions.

A brief history of the Masters in Archives and Records Management (MARM) at UCL; the archives course sits within the Department for Information Studies, and this is the only department in the UK which holds together in one place programmes in library and information studies, information science, archives and records management, publishing, and digital humanities. The MA in Archives \& Records Management concentrates on the management of records and archives in a variety of digital and hard copy formats. Students learn to organise, interpret and provide access to a wide range of records and archives, focusing on both the management of records for on-going purposes, and their selection, preservation and accessibility for future uses including historical research.

Archives and records management at UCL is one of the longest-established archival education programmes in the English-speaking world. Taught by leading experts in the field, the programme draws on staff's involvement in innovative projects as well as their extensive practical experience of archives and records work. Indeed, although the programme's content and structure have changed greatly over the years, keeping pace with developments in the archives and records disciplines and in information technology, the UCL programme continues to maintain the highest standards in the teaching of archival principles and practice, as laid down by its founder, Sir Hilary Jenkinson.

The Archives and Records Management MA provides the skills and knowledge that are needed by new entrants to the profession in the United Kingdom and abroad. Students learn to manage and preserve records created in the present and those inherited from the past for use in the present and future. In 2012-2013 this programme was merged with the MA/Diploma/ Certificate in Records and Archives Management (International) to create a more digitally aware and internationalised curriculum designed for students from the UK and overseas who intend to pursue a career in archives or records management. 
The MA is now formed of five core modules:

- Concepts and Contexts

- Creation and Capture

- Curation and Stewardship

- The Record-keeping Professional

- Access and Use of Archives and Records

Whilst these modules aim to provide a solid foundation of conceptual knowledge and practical skills, students' individual interests can be explored in depth through two optional modules chosen from the following subject areas:

- Collections Care

- Database Systems Analysis

- Digital Resources in the Humanities

- Information Governance

- Manuscript Studies

- Reading and Interpretation of Archives from 1500

As is clear, the preservation and conservation elements are now very successfully embedded in the MARM programme, and this is delivered through a combination of lectures, seminars, computer laboratory practicals and classroom practicals, with a strong emphasis on informal teaching and the acquisition of practical skills. Assessment is through a mixture of essays, reports, and practical assignments such as cataloguing and complex problem solving scenarios.

Students benefit from the Department of Information Studies' excellent links with employers in the information professions, which provide them with "real life" experience through guest lectures, visits and a two-week work placement. As part of the programme students also receive specific careers advice, including how to construct CVs. In the longer term the programme equips students with the skills and knowledge to have long and successful careers in their chosen field and become leaders in their profession.

The Main module of Curation \& Stewardship deals with the issues and activities involved in maintaining authentic and usable records over time and through change. It aims to enable students to build a clear appreciation of the vulnerability of the physical and virtual record, and to develop the knowledge and skills to ensure that such records are maintained and that the risks to them are properly addressed and managed. To this end, students should, by the end of the module, be able to:

- Explain what is meant by and involved in the preservation and management of records over time

- Identify and apply the most appropriate standards, strategies and processes to ensure the ongoing preservation of records in a variety of contexts

An indication of the structure and timetable, and a more detailed description of the content of the module is given below:

\section{Week 1 - Introduction;}

Weeks 2-3 Taking Custody including topics such as; collections development, collecting policies, stages in accessioning, interviewing donors, terms of deposit, automated metadata extraction, accessions registers and cataloguing policies;

Week 4 - Building the Store - including topics such as; the key characteristics of paper and parchment, the chemistry of paper, the nature of acid deterioration, security, the use of off-site storage or alternative approaches and building green and sustainable archives;

Week 5 - Managing the Store - including topics such as; the influence of standards on funding for archive buildings, a review of new building examples and consideration of how to address risks such as flood, pollutants, dust and pests, monitoring procedures and the use of packaging as both protection and support;

Weeks 6 and 7 - Processing - including topics such as; the application of the principles of prove- 
nance and original order, archival descriptive standards, including ISAD $(G)$, the qualities of good archival description and indexing and vocabulary control;

Weeks 8 and 9 - Preservation Planning - including topics such as; standards. e.g. PD 5454: 2012 and PAS 198: 2012, the function and application of benchmarking, disaster planning and emergency response, the use and function of a preservation policy, surrogacy options and digital preservation;

\section{Week 10 - Conclusions.}

This programme also includes 4 afternoons in a local repository taking part in a pre-arranged practical called "Processing Assessment" which involves the students in assessing a specific collection, leading to a formal written processing plan as a part of the student coursework. This assessment is designed to help the students develop "professional judgement" and to gain experience in reaching decisions with incomplete information. It is designed to test that the students apply the knowledge learnt during the module to reach a reasoned and justifiable decision that is informed by professional standards, ethical principles and an awareness of the surrounding contextual factors. The key areas are Collection Details, Arrangement and Description and Rehousing and Preservation.

In addition, this programme also includes two afternoon lectures by leading archive professionals - one on buildings and the other on digital preservation - and one visit to a major local government archive to view a range of preservation activities, including:

- An outline talk by Collections Care Manager

- A tour of building (energy, storage, preservation issues)

- A visit to the Conservation Studio - conservators talk about projects and general techniques

- A visit to the Imaging and Reprographics to see digitisation in practice

- View the boxmaking section at work, and to see the computerised machine for tailor-made boxes

One of the key strengths of this module is that it is taught by a preservation specialist and an archivist - both the beginning and end sessions are jointly taught - and this presents a positive approach to the students by underlining the similarities between the two specialisms of preservation and cataloguing programming. It is also hoped that this example will impact on the future archivists' appreciation and knowledge of conservation and preservation activities, and how these underpin archival management. It is often the case that senior archivists will ne given the responsibility of managing conservation and preservation services. Additionally, the training also takes account of the increasing possibility that the newly qualified archivist will be working on their own and so will have to make preservation decisions without reference to others.

For those who wish to take their collection care knowledge to the next level, in the second term there is a choice module, Collections Care, which is Optional for MA, Diploma and Certificate students in Library and Information Studies, Archives and Records Management, Records and Archives Management (International). This module is also available for short course students, which serves to bring in a wider range of experience and expertise - and this can add to the students' overall learning. Likewise the module participants are often from the MARM, Library and Digital Humanities courses. The purpose of this course is to build upon and extend the study of preservation issues affecting archive and library collections. To ensure that participants get the full benefit of the analysis and discussions, it is advised that students need a good feel for, and basic grounding in, preservation management and planning.

This module analyses in greater detail the challenges inherent in preservation management, conservation programming and the collection needs of library and archival material to include both photographic media and digital records. Interestingly, students that undertake this module often see its benefit for their career-ladder, by enabling a wider knowledge of the issues surrounding collection management, and it appears to be particularly popular with Library students who are seeking future employment in Special Collections departments.

A range of guest speakers present most of the topics which includes, the complexities inherent in specifying buildings for collections, the application and use of standards, options for moving archives and libraries, a practical session utilising digital preservation software, the preparation of collection material for digitisation programmes, the challenges presented by photographs, film, and audio visual materials, 
and the management of digitisation projects (including the impacts of the conservation needs of collections). There are also opportunities for the students to hear experts talk on the role of preservation as an integral part of collections management, and on the cleaning and handling of rare books.

By the end of this module, it is intended that students will have an in depth knowledge of preservation principles and will be able to formulate both conservation and preservation programmes to address the needs of both library and archival collections. The course builds on the content of the archive module on preservation, but it is not essential to have taken that first.

The Collections Care module timetable and structure is set out below:

- Week 1 - Preservation course outline and aims; the role of preservation in the long-term care of collections;

- Week 2 - The specification and project management of new archival building;

- Week 3 - The interpretation and utilisation of standards;

- Week 4 - The function and integration of environmental monitoring within preservation

- Management;

- Week 5 - Visit to the University of the Arts London, Archives and Special Collections Centre, which includes the Stanley Kubrick Archive;

- Week 6 - Moving archives and library collections; cleaning handling and book structure;

- Week 7 - The practical application of digital preservation software;

- Week 8 - Photographic preservation;

- Week 9 - Preserving sound archives; visit to the British Library Sound Archive;

- Week 10 - The conservation perspective on digitisation projects; collection needs.

So, the development of a more integrated and flexible form of teaching is effectively responding to the current changes and needs of those entering the archive sector. UCL students are definitely competitive in the overloaded job market, which is itself being undermined by cuts in resources and the reduction of full-time positions for newly qualified archivists.

A quick assessment of the other university courses offering archive management in the UK has shown that UCL is the only course (of the main four) that employs a specialist to teach the preservation and collections care elements. This is clearly a very specific and strong commitment from UCL, as the preservation teaching post is paid for as a visiting lecturer. The big question is "Do the students get a better experience from being taught by a practicing professional"? All the other courses cover preservation as part of the overall care of collections, and obviously those that provide a distance learning module (UCL does not) have to accept that the coverage is more general.

One of the weaknesses of teaching a very theoretical subject, and one that has to take place within a university setting, is that the options for gaining practical experience are difficult to achieve - this is partly due to class size (at UCL the annual archival cohort is about 25) and also the difficulty in finding a venue large enough to accommodate this many students, coupled to the need for any institution to offer this activity for free. Having a practicing professional provide the teaching, and especially in the author's case, a self-employed professional, brings a wide range of anecdotal information to back up the theory. In addition, the author has a large collection of photographs illustrating the issues covered in the teaching, and this serves to connect the students with the reality of the situations they will face in the future, and also serves to embed decision-making.

Another factor that continues to challenge and shape the development of the MARM programme is student expectation. Most of the students will have a number of volunteer and/or paid placements in their portfolio of experience - indeed it is a requirement of the course. The full requirement is a minimum of an upper second-class Bachelor's degree in a relevant discipline from a UK university, or an overseas qualification of an equivalent standard, alongside a significant period of paid or voluntary employment in an archive or records service, or in a post with management responsibility for archives or records. This extended experience means that students starting the course already have a clear understanding of the world of archives and increasingly have a high expectation for the digital content of their teaching.

This factor presents a wide range of challenges to the teaching team, especially as most of the students will get work in archives that have primarily analogue collections. The conundrum is how to effectively include digital content? This is particularly so for the preservation sections of the module. Clearly the 
need to preserve digital information is as important, and in some ways (amongst UK archives), more important, due to a current failure in general to address this issue. However, the solutions to digital preservation are no more straight-forward than for paper archives - the information content still needs to be safe-guarded and the carrier of the information (be it a document or a hard drive) protected and preserved.

UCL is very aware that the expectation of the students, and the content of the programme it provides, is vital when students choosing a university. UCL is still one of the UK's top choices for students, but in an ever-growing competitive environment, and when aligned with the significant costs of attending university in the UK, the MARM programme needs to constantly review and change to meet needs, whilst ensuring that the core content is professionally sound and fit-for-purpose.

The coursework for both of the modules, and especially for the Collections Care module, sets a couple of questions that require the students to create a scenario within a structured "plot". The information provided is purposely vague, as the students need to be challenged - this is a Masters programme. Additionally, one of the questions requires the students to answer the question as a report to management, and this proves very challenging for each annual cohort. However, report writing in the current professional climate is vital, and being able to tailor thoughts and arguments for a specific, and non-professional audience is a very important skill.

\section{Conclusion}

All new archive professionals need to have a solid understanding of preservation and collection care issues. The key focus of those with responsibility for the collections in their care is to provide access to the information contained in the records; this access will be undermined if the carrier of the information is damaged to such a degree that it cannot be handled. Digitisation as a method to provide a substitute to the original is one of the ways to reduce the impact of use on fragile and unique materials, but it is only one of the options. The maintenance of the building, and a clear understanding of risk to the collections are vital to ensure long-term preservation. The building, and the resultant impacts of poor management and maintenance, is the one comparable issue that affects all archive professionals, whatever their language or national resources. So it is imperative that archival students have sound and detailed grounding in the issues of collection care and building management. At UCL this is provided via the commissioning of a practicing collection care professional and the university believes that this is vital for the effective development of all archivists and into the future.

\section{References}

Aberystwyth University; MA Archive Administration: Archive Management: Archive Services, available at: https://www.aber.ac.uk/en/modules/deptfuture/ILM1620/ (accessed April 2017)

Forde, H. and Rhys-Lewis, J., Preserving Archives, $2^{\text {nd }}$ edition, Facet Publishing (2013)

Liverpool University Centre for Archive Studies; Archives \& Records Management - Managing Services, Access \& Preservation, available at: https://www.liverpool.ac.uk/study/postgraduate-taught/taught/archives-and-records-management-ma/module-details/ (accessed April 2017)

University College London; Department of Information Studies, available at: https://www.ucl.ac.uk/dis/aboutdis (accessed April 2017)

University College London; MA in Archives \& Records Management, available at: https://www.ucl.ac.uk/dis/ study/pg/TMAARMSING01B (accessed April 2017)

University College London; INSTG060: Curation \& Stewardship, available at: https://www.ucl.ac.uk/dis/study/ pg/INSTG060 (accessed April 2017)

University College London; INSTG002 Collections Care, available at: https://www.ucl.ac.uk/dis/study/pg/INSTG002 (accessed April 2017)

University of Dundee; Centre for Archive \& Information Studies: Archive Services, Access \& Preservation, available at: https://www.dundee.ac.uk/cais/programmes/modules/archiveservicesaccesspreservation/ (accessed April 2017)

Typology: 1.04 Professional Article

Submitting date: 08.04.2017

Acceptance date: 05.05.2017 